\title{
Implementation of Industry 4.0 Using E-learning and M-learning Approaches in Technically-Oriented Education
}

\author{
Dusan Mital', Darina Dupláková, Ján Duplák, Zuzana Mital’ová, Svetlana Radchenko \\ Technical University of Kosice, Faculty of Manufacturing Technologies with a seat in Presov, Bayerova 1, \\ 080001 Presov, Slovakia
}

\begin{abstract}
Within the states of the European Union, the traditional system of education in the concept of student-teacher-department dominates in the $21 \mathrm{st}$ century. Although technically oriented teaching is transferred to the digital world a bit more demanding compared to teaching in the humanities, there is a period of significant modernization and digitization in the field of education of technical subjects using a wide range of Learning management system approaches. This article is focused on the implementation of industry 4.0 using E-learning and M-learning approaches in technically-oriented education. The introductory part provides an overview of the issues of the Learning Management System by the concept of Industry 4.0. Based on research studies, the next part of the article provides a brief overview of the most well-known LMS systems with a subsequent description of the most suitable system. The main part of the article describes the implementation of $E$ learning and M-learning approaches on a specific example from the educational practice implemented at the Faculty of Manufacturing Technologies with a seat in Prešov.
\end{abstract}

Keywords - Industry 4.0, E-learning, M-learning, Education, Learning Management System.

DOI: 10.18421/TEM101-46

https://doi.org/10.18421/TEM101-46

Corresponding author: Darina Dupláková,

Technical University of Kosice, Faculty of Manufacturing Technologies with a seat in Presov, Bayerova 1, 08001 Presov, Slovakia.

Email: darina.duplakova@tuke.sk

Received: 09 October 2020.

Revised: 19 December 2020.

Accepted: 28 December 2020.

Published: 27 February 2021.

(c))BY-NC-ND C 2021 Darina Dupláková et al; published by UIKTEN. This work is licensed under the Creative Commons Attribution-NonCommercial-NoDerivs 4.0 License.

The article is published with Open Access at www.temjournal.com

\section{Introduction}

Recently, there has been a trend to modernize the educational environment by using a wide range of information and communication technologies under the Industry 4.0 concept focused primarily on the digitization of all supporting physical resources and their integration into systems. [1], [2] The basic framework of the Industry 4.0 concept with the connection of digital technologies consists of four basic units [3]:

- A system for receiving and organizing information, data, and knowledge;

- Implementation and proper management of incoming flows;

- Organization of processes and systems at the virtual level;

- Digitization of real existing processes and systems.

An exception in the process of digitization is not educational processes in technical fields, the preparation of which in digital form is quite demanding, but necessary for the following reasons [4]:

- an increase in the amount of information in which it is necessary to orientate,

- the need for more education, which can be obtained in school desks,

- greater flexibility in the teaching process and greater emphasis on the student's independent work,

- the need to obtain information faster and better,

- higher quality in external forms of study, intensification of contact with one's students,

- new possibilities of external cooperation and cooperation with foreign universities directly in teaching. 


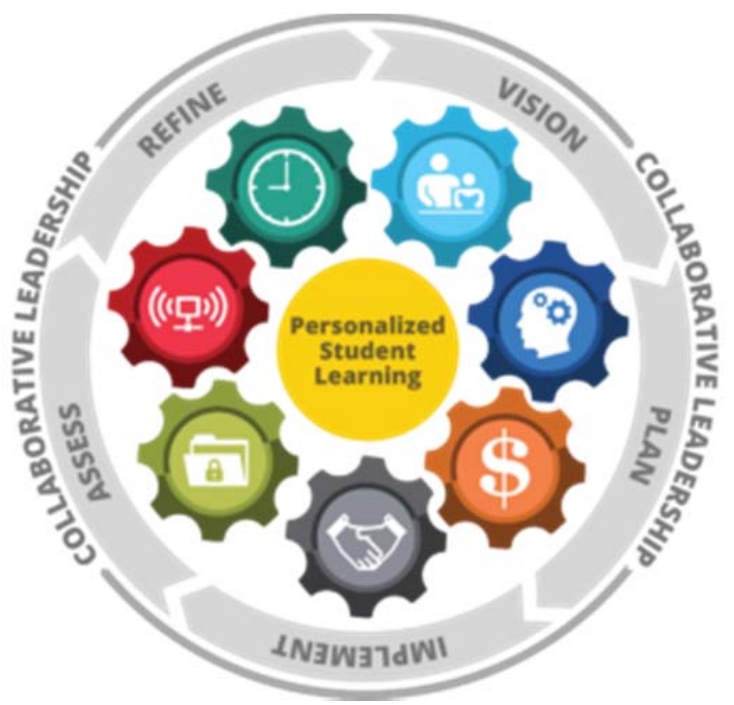

Figure 1. The conception of digital learning [4]

Digitization of the teaching process is represented by the form of E-learning and understood as technology-based learning. In a broader context, it is possible to understand this concept as multimedia support of the educational process using information and communication technologies, whose primary task is to increase the quality and availability of education. In a narrower context, however, the term is understood as education, which is supported by modern technologies and which is implemented through computer networks (most often the Internet), while allowing digital content to be transmitted to each member of the educational institution or community. When using the online teaching system, it is possible to use two basic types of the teaching process [5]:

- Synchronous teaching - constant connection to the network, communication between the teacher and the student in real-time, teaching carried out in a virtual classroom,

- Asynchronous teaching - communication between teacher and student through emails or discussion forums, study materials can be transferred to a computer and part of the teaching process can be implemented offline.

The basic advantages of e-learning can include:

- Diversification of the approach to the teaching process;

- Adaptation of the study to the individual;

- Ensure easier organization;

- Ensuring increasing computer literacy.

The basic disadvantages of E-learning can include:

- Increased demands on technology;

- Time-consuming preparation of materials;

- Time-consuming control of created and entered tasks;

- Elimination of the study of books other than materials presented through a computer system.

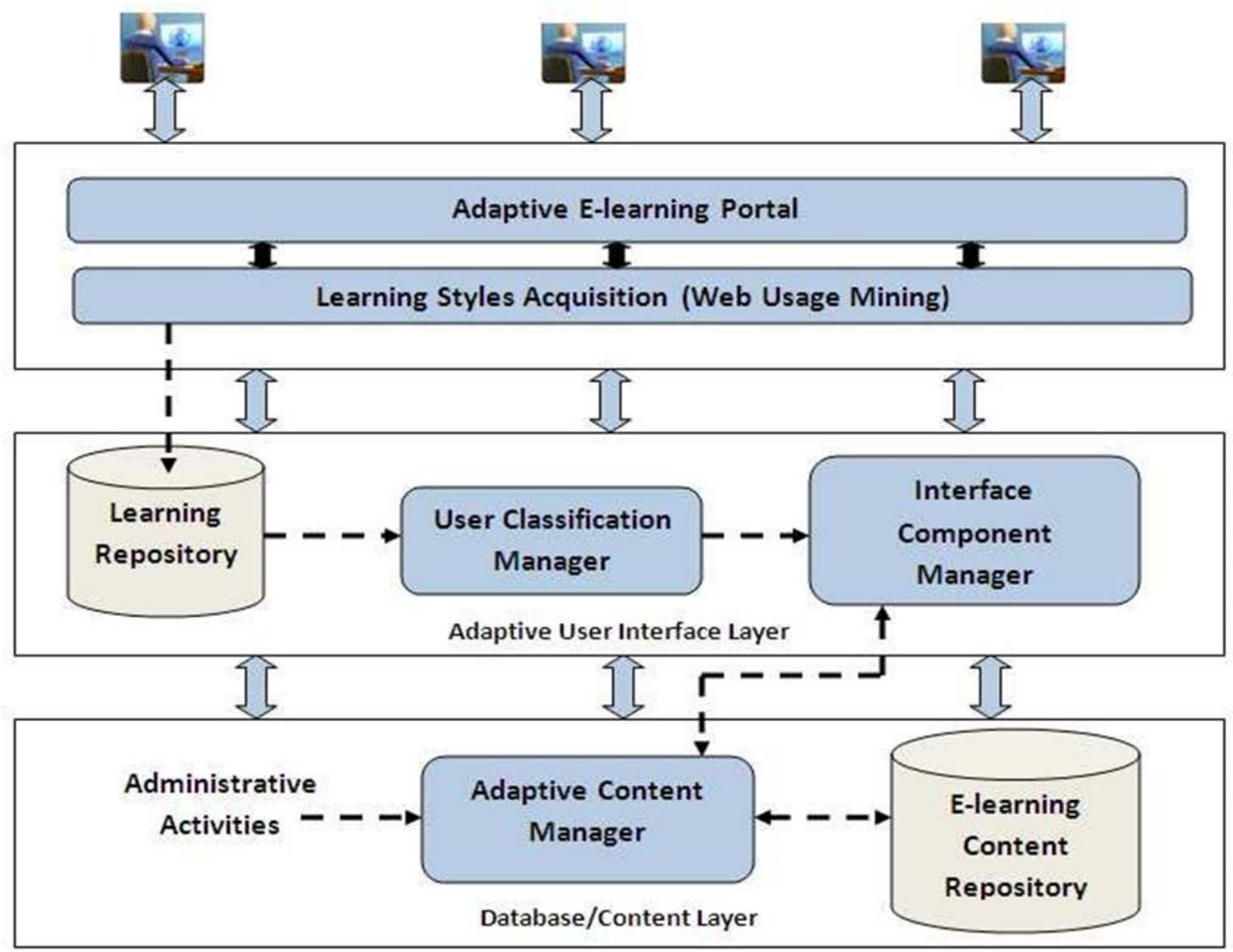

Figure 2. Approach to E-learning basic architecture system [6] 
The online form of the teaching process has been evolving for several years, and its development has been divided into three basic levels:

- Computer-Based Training - a computer program offers the student clear and didactically modified information in meaningful steps, the student enters into a dialogue with computer teaching software, programs are created so that students have to process information in an active form, provides the opportunity to deepen the curriculum by completing test tasks;

- Web-Based Training - distribution of materials within the pedagogical process via the Internet, communication between teacher and student is realized on a synchronous and asynchronous level, provides the possibility of immediate updating of information without complications and additional financial costs, an important part is an interactivity;

- Learning Management System - innovation of the WBT system, but with the content of tools for creating and managing courses, for testing and feedback, for course administration, evaluation and communication.

Currently, the highest - third level, Learning Management system, a software application designed for documentation management, monitoring and reporting on educational programs, classes and online events, e-learning programs and educational content based on Web technology, is used in pedagogical practice whose task is to plan, implement and evaluate a specific learning process. [7] LMS systems can be specified as systems that integrate various online tools for communication and study management (bulletin board, discussion forum, chat, whiteboard, records, etc.), and at the same time make teaching materials or teaching content available to students online or offline.
The basic classification is as follows [8]:

- CMS - providing mainly course management,

- LCMS - ensuring mainly the creation of study content,

- ELMS - providing comprehensive management, creation, and administration of education.

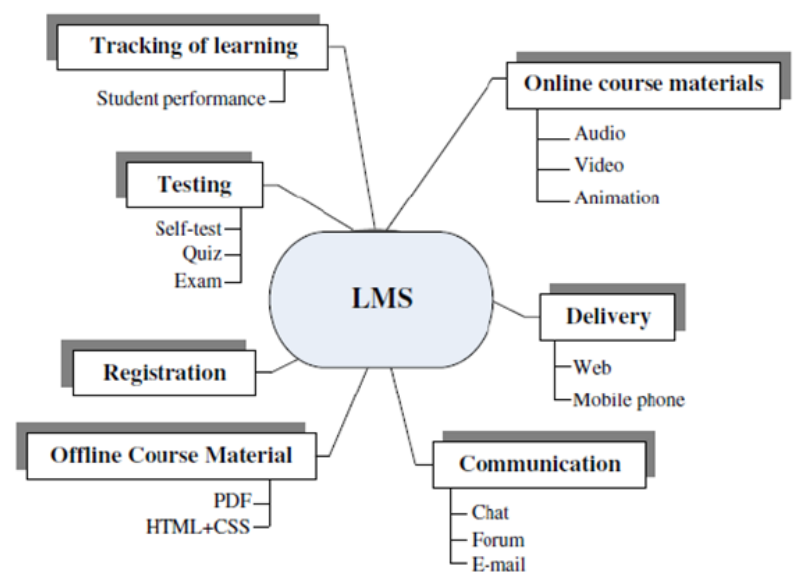

Figure 3. The basic structure of LMS [9]

The basic idea of this type of education should not be to replace the real form of teaching but should serve as an important and supportive tool in the educational process. It ensures faster and more efficient dissemination of information, selects the suitability, need for available information and improves the educational process itself. [10]

\section{LMS Systems Used in Technically Oriented Education}

The current market provides many software solutions through which the pedagogical process can be ensured. The following Table provides a brief overview of selected software solutions with basic specifications, which are most often used in technically oriented education.

Table 1. LMS software overview

\begin{tabular}{|c|c|c|c|c|c|}
\hline $\begin{array}{c}\text { Name of } \\
\text { LMS systems }\end{array}$ & Chamilo & $\begin{array}{c}\text { Google } \\
\text { Classroom }\end{array}$ & ATutor & ILIAS & Moodle \\
\hline Designer & $\begin{array}{c}\text { Chamilo } \\
\text { Association }\end{array}$ & Google & $\begin{array}{c}\text { Inclusive Design } \\
\text { Research Centre, } \\
\text { OCAD University, } \\
\text { ATutorSpaces }\end{array}$ & $\begin{array}{c}\text { University of } \\
\text { Cologne }\end{array}$ & $\begin{array}{c}\text { Martin } \\
\text { Mougiamas } \\
\text { Moodle HQ } \\
\text { Moodle } \\
\text { Community }\end{array}$ \\
\hline $\begin{array}{c}\text { Genre/Type/ } \\
\text { Licence }\end{array}$ & $\begin{array}{c}\text { LMS 1.11.10/ } \\
\text { GNU/GLv3 }\end{array}$ & $\begin{array}{c}\text { G Suite for } \\
\text { Education }\end{array}$ & $\begin{array}{c}\text { LCMS/ Online } \\
\text { learning platform/GPL }\end{array}$ & $\begin{array}{c}\text { PHP and MySQL/ } \\
\text { NU General } \\
\text { Public License }\end{array}$ & GNU/GPL3+ \\
\hline Description & $\begin{array}{c}\text { Course } \\
\text { Management } \\
\text { System }\end{array}$ & $\begin{array}{c}\text { Open } \\
\text { Source } \\
\text { LMS }\end{array}$ & Open Source LMS & Open Source LMS & $\begin{array}{c}\text { Open Source } \\
\text { LMS }\end{array}$ \\
\hline
\end{tabular}




\section{Chamilo}

The software solution is a freely available system that focuses on improving access to education on a global scale. This software is most often used in the educational process due to:

- publishing basic information about the subject,

- expanding access to study materials,

- creation of interactive educational aids and tests,

- student-teacher cooperation,

- assignment of semester assignments and projects, and etc.

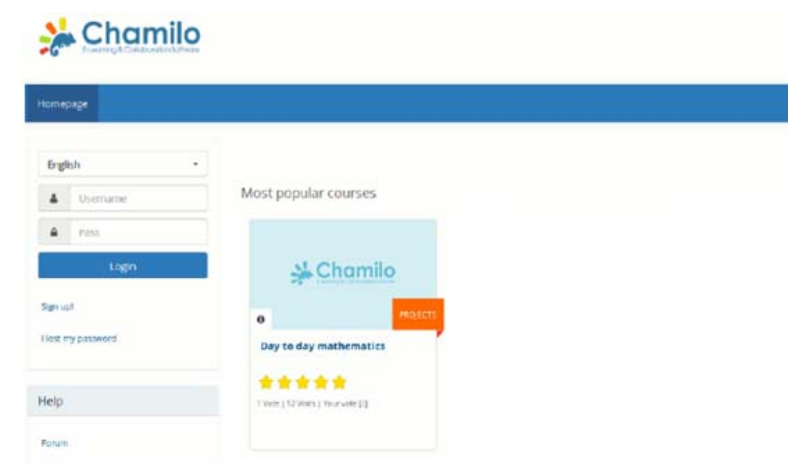

Figure 4. Start screen - Chamilo

The software solution provides a clear user environment and easy operation, which is provided by working tools in the form of pictograms shown in the following Figure.

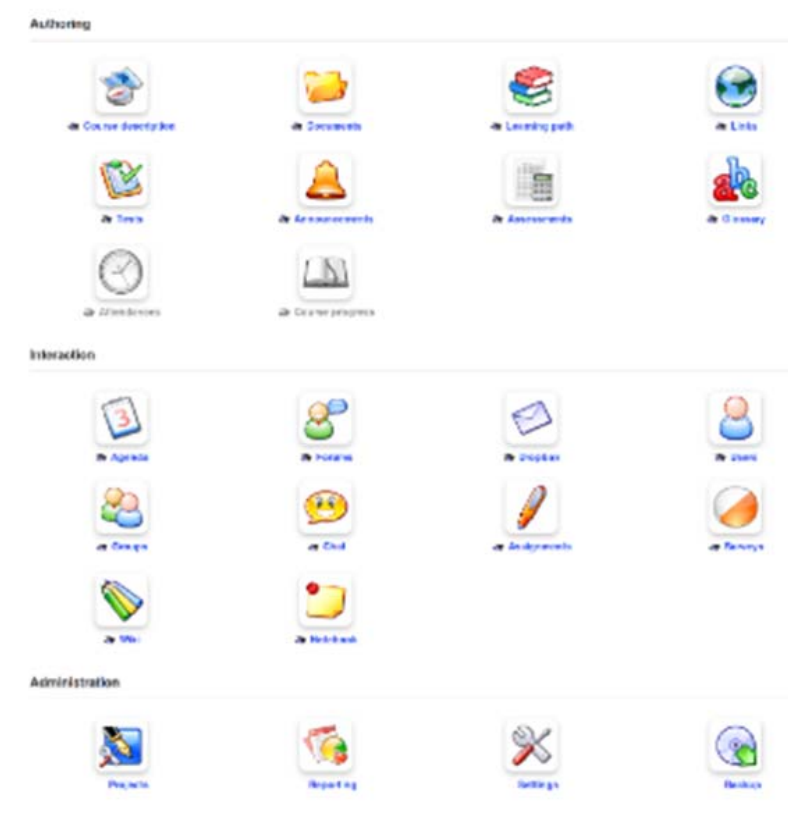

Figure 5. Basic overview of Chamilo work tools

Possibilities of creating an educational unit and control activity are part of almost every e-learning product. Through clear statistics, it is possible to create partial and overall student evaluations, as shown in the following Figure.

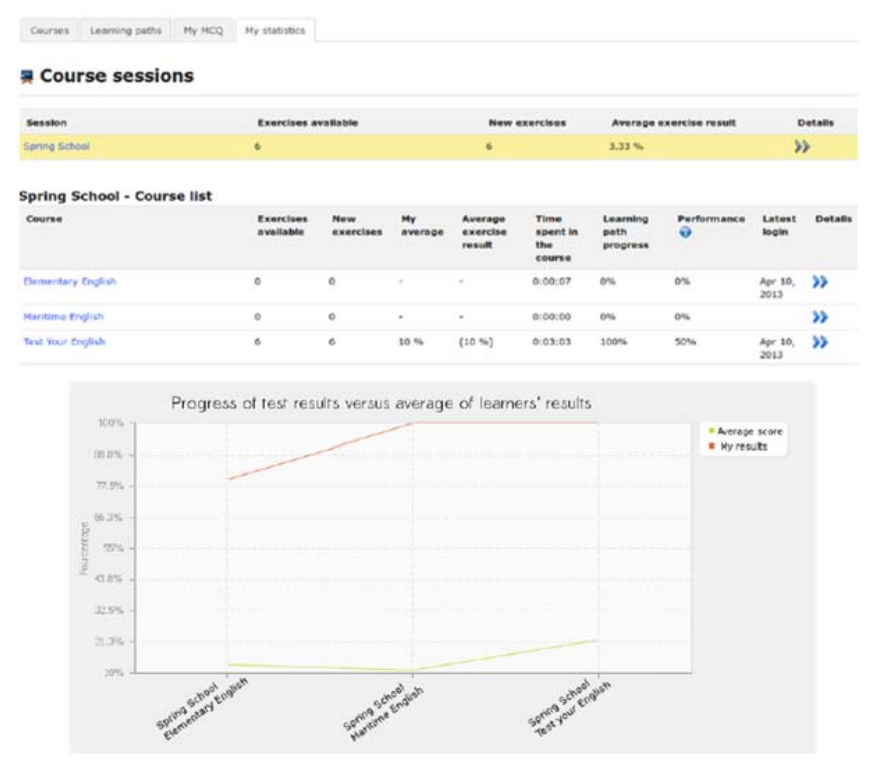

Figure 6. Basic evaluation of course - Chamilo

\section{Google Classroom}

Since 2014, a free software solution of e-learning from Google - Google Classroom - is also available. The system can be used by users who have an account through Google.

$\equiv$ Google Classroom
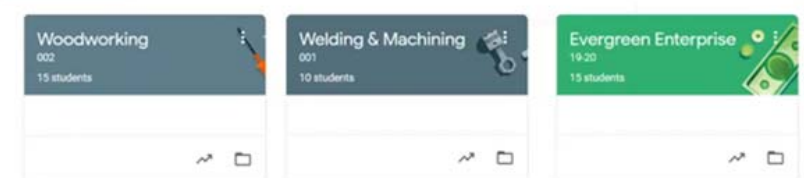

$\sim$

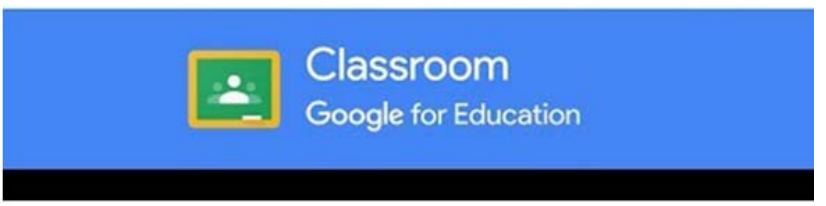

Figure 7. Start screen - Google Classroom

This software allows educators to quickly create and manage defined tasks, while the platform provides standard feedback. The platform provides E-learning and M-learning education, as the access is implemented via a standard web browser and also via a mobile application. However, the platform does not provide the possibility of entering test tasks or establishing a discussion forum that supports the online connectivity of the student-teacher system.

\section{ATutor}

ATutor is an online e-learning system based on the Learning Content Management System (LCMS), created concerning availability and adaptability. It allows trainers to easily develop online courses and present them in the structure of the learning environment. 


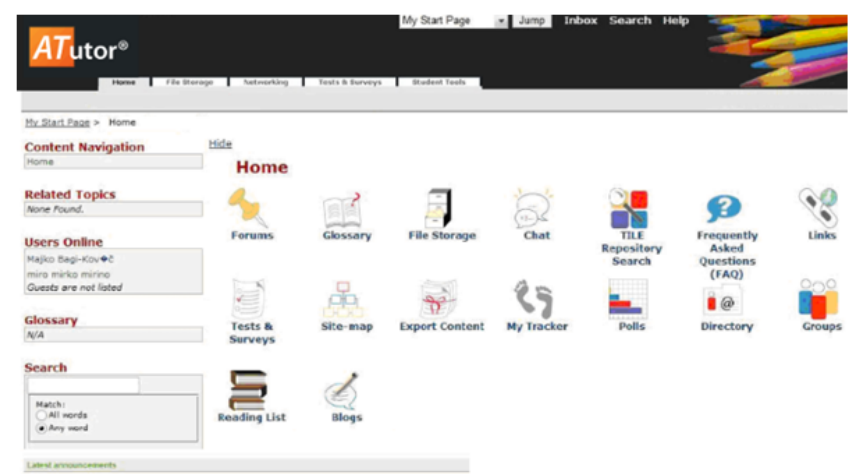

Figure 8. Start screen - ATutor

Online students can navigate content in a variety of ways, adapting it to their learning style, or learning method, of materials available online. The strength of this system is at first glance intuitive operation and the austerity of design appearance. Unlike the Google Classroom system, it is possible to create partial and final test tasks via the ATutor interface by using direct creation in the software interface or by uploading test tasks.

\section{ILIAS}

Ilias works similarly to Google Classroom based on open source code using a web interface. Through the ILIAS system, it is possible to create learning content, tools for its creation provides the possibility of creating forums and through its functions can create statistical evaluations of defined tasks. This elearning tool can be understood as a type of library that provides students with teaching materials, using the principles of an open information platform.

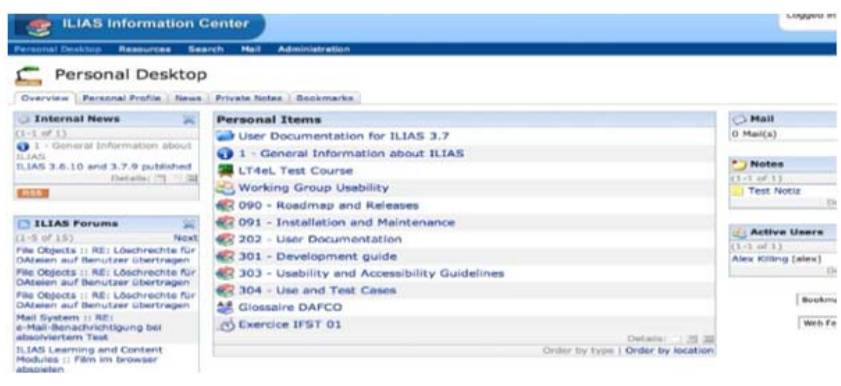

Figure 9. Start screen - ILIAS

\section{MOODLE}

Moodle can be specified as a software package for creating learning systems and electronic courses on the Internet. It is a constantly evolving project, designed and based on new blue trends and approaches to education. At the heart of this approach is the idea that people learn the most if there are interactions between them and the study materials as well as between the people themselves. The system is provided free of charge as GNU General Public License open-source software, which is freely available. The Moodle infrastructure supports many types of extensions (plugins), which can be the following:

- activities (including word and math games);

- source files and questions;

- data fields (for database activity);

- graphic themes;

- verification and authentication methods;

- methods of registration;

- content filters.

One of the biggest advantages of the system is the flexibility in creating courses. Every single user can customize it to their needs. This is made possible by freely distributable modules, and their number has an increasing tendency.

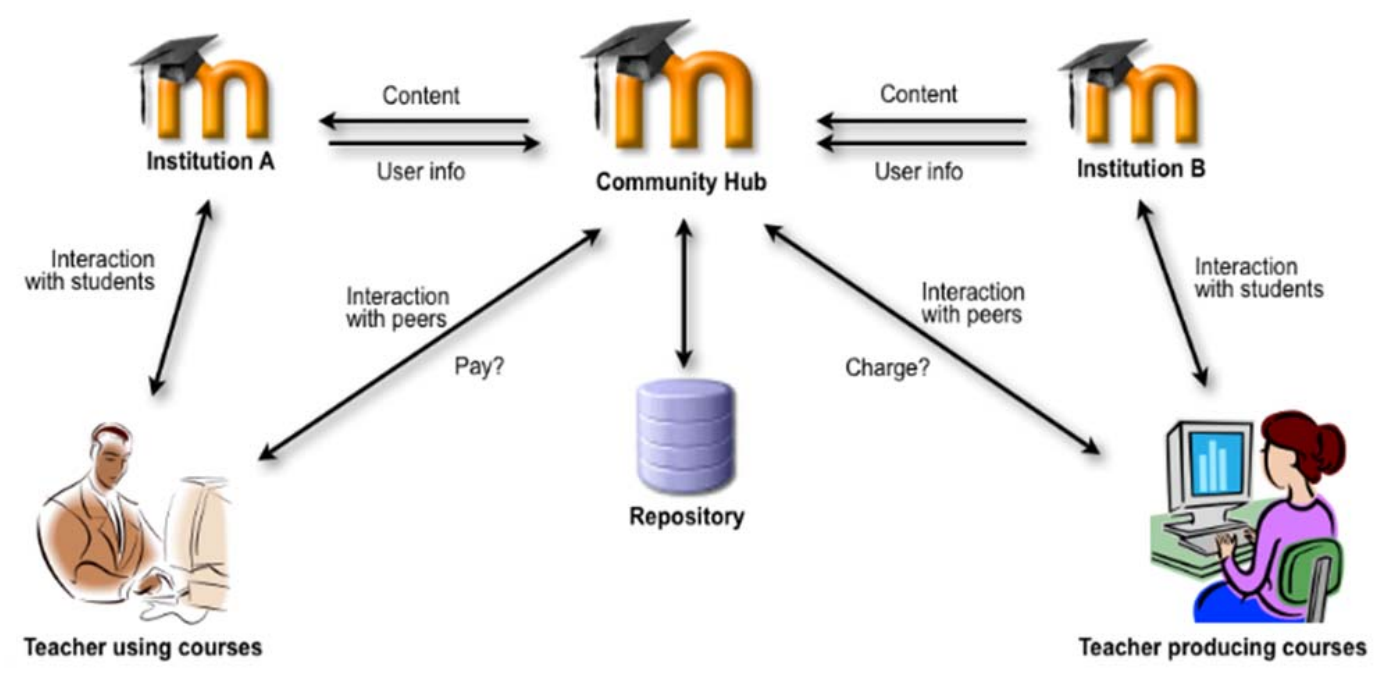

Figure 10. Structure of Moodle [11] 


\section{Implementation of Industry 4.0 using E- learning and $M$-learning in practice}

Determining the importance of Implementation of Industry 4.0 using E-learning and M-learning in practice can be declared directly on the examples of the educational process implemented at the Faculty of Manufacturing Technologies, which supports the digitization of the teaching process using the Moodle system. Through LMS Moodle, it is possible to implement the teaching of technically oriented subjects at the theoretical level in full within the web interface, without the need to install additional software.

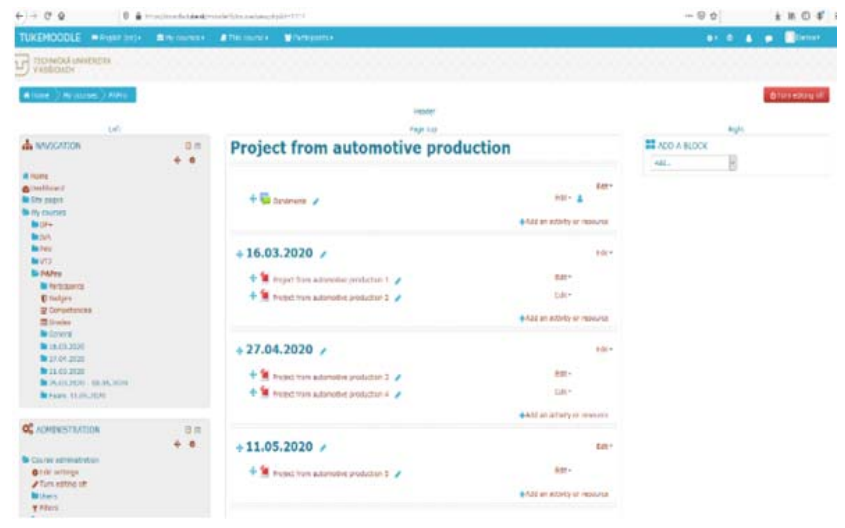

Figure 11. The main page of the selected course

In each of the subjects, it is possible to create new sections and add activities or resources. It provides options for entering semester projects, lessons, lectures, files, study materials and e-Books, links to websites and videos (custom recordings or hyperlink application).

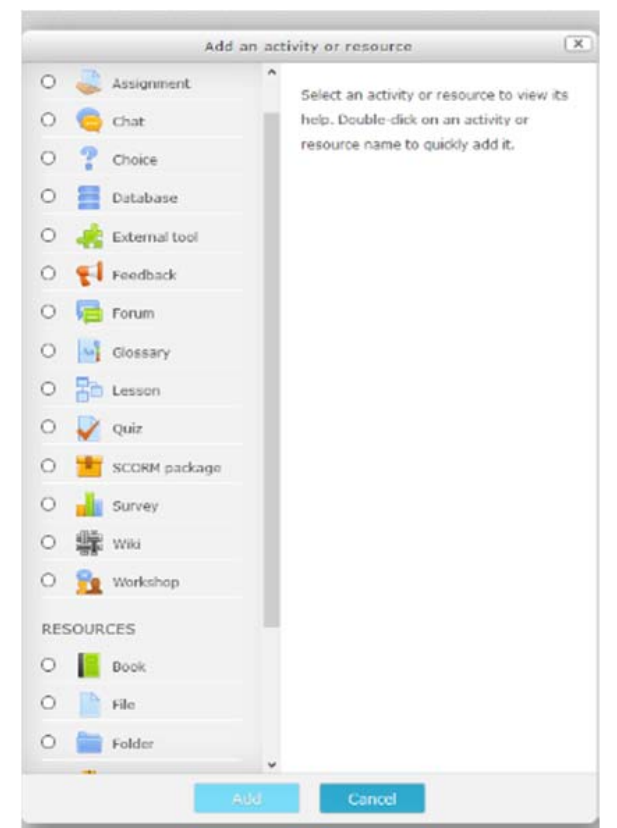

Figure 12. Adding options of activities or resources

Through the basic interface, the teacher can quickly and efficiently define the requirements and conditions for the elaboration of a semester project or create a test individually for each student or in groups. In the basic determination of requirements for the semester project, in addition to the basic description, availability is also provided, through which the teacher can limit the terms associated with uploading and also the method of uploading supported formats, number of uploaded files, notifications, grade, etc.

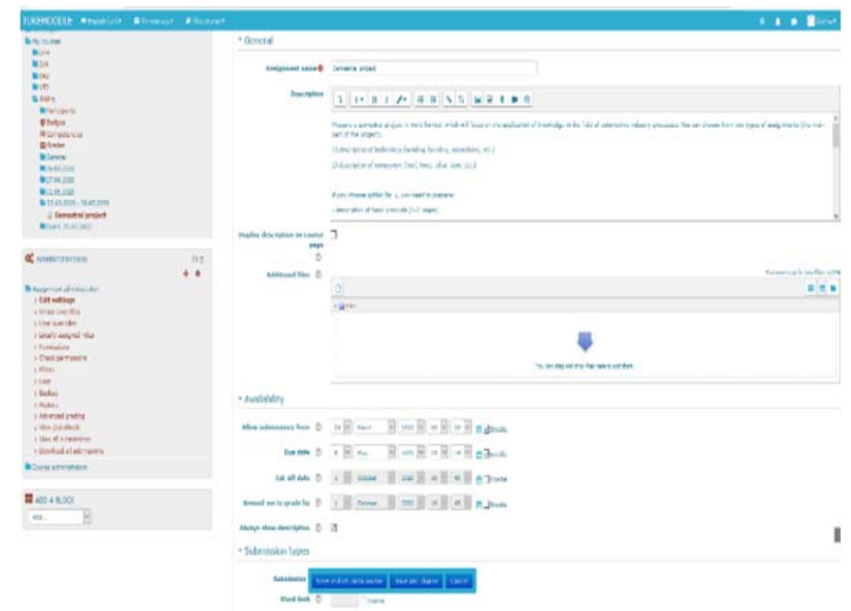

Figure 13. Creating an assignment for the elaboration of a semester project

Creating test tasks is also broad-spectrum, as a variety of determining tasks is provided, such as matching, essay, numerical, short answer, multiplechoice, etc.

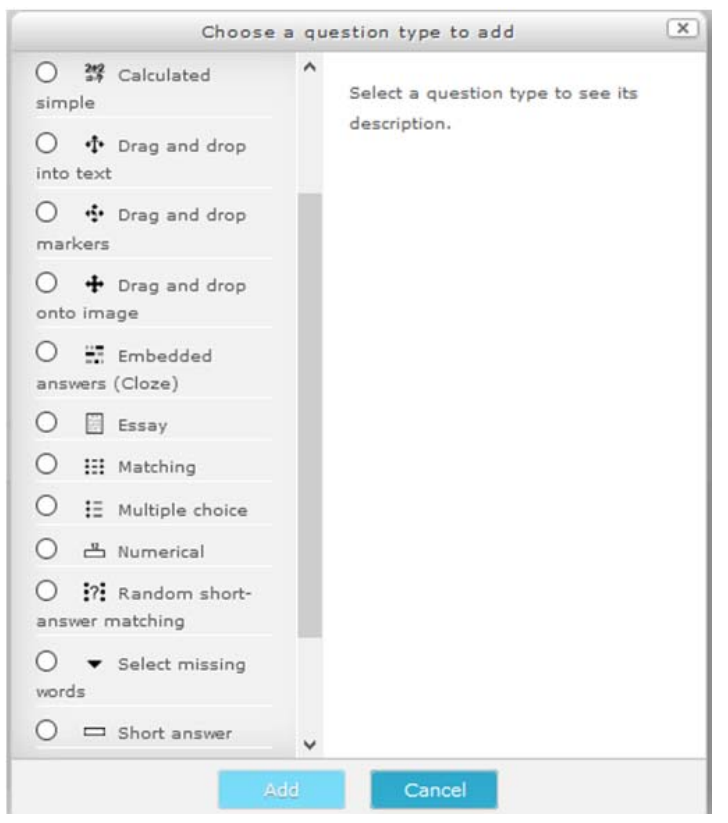

Figure 14. Test creating

Student evaluation and the whole structure of tests can be analyzed through the Statistics function, which provides a wide range of data such as standard deviation, facility index, random guess score, discrimination index, etc. Through export functions, the subsequently created data bank can be transferred to statistical software with the subsequent creation of additional analyzes. 


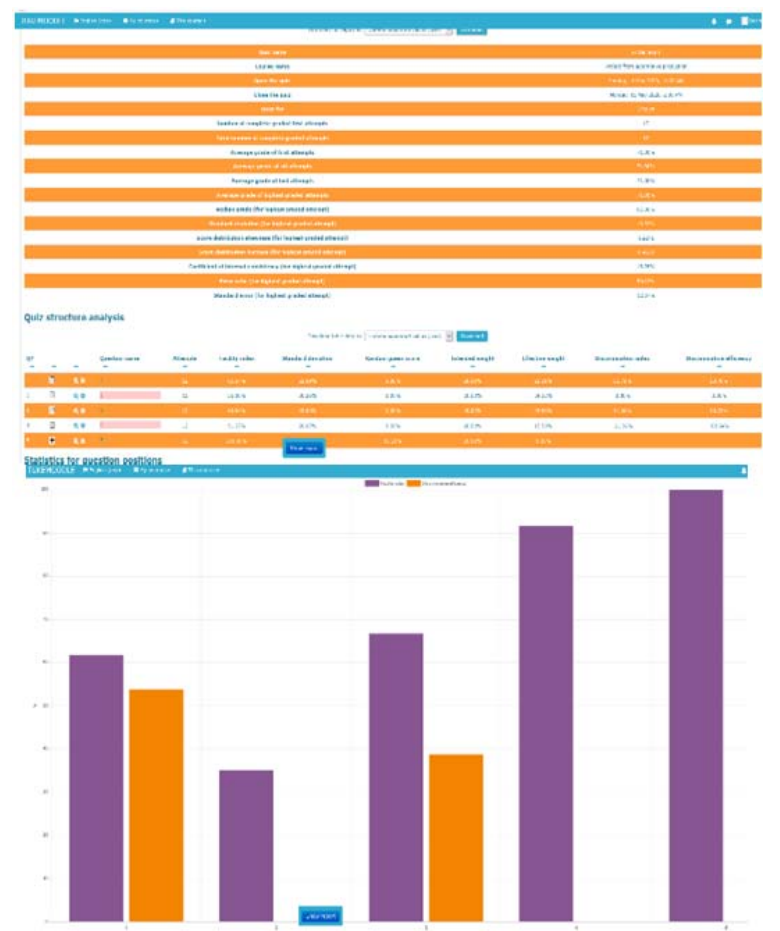

Figure 15. Evaluation and test statistics

The interactivity of the Moodle system lies in the possibility of using the concept of E-learning as well as M-learning. From the pedagogue's point of view, Moodle is an equally suitable and full-fledged tool for the implementation of E-learning and M-learning.

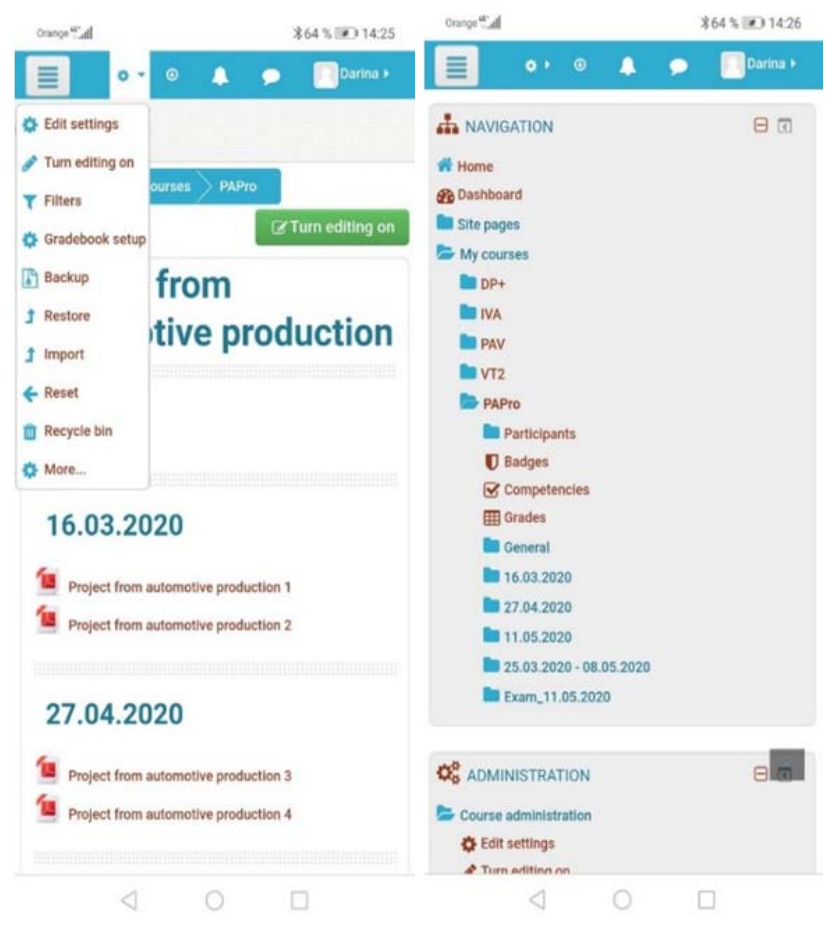

Figure 16. Moodle interpretation as M-learning toolbasic menu and navigation panel
Modification within the M-learning tool Moodle compared to E-learning occurs in the display, as the difference of individual interfaces is created. However, the functionality and content of the tools are the same.

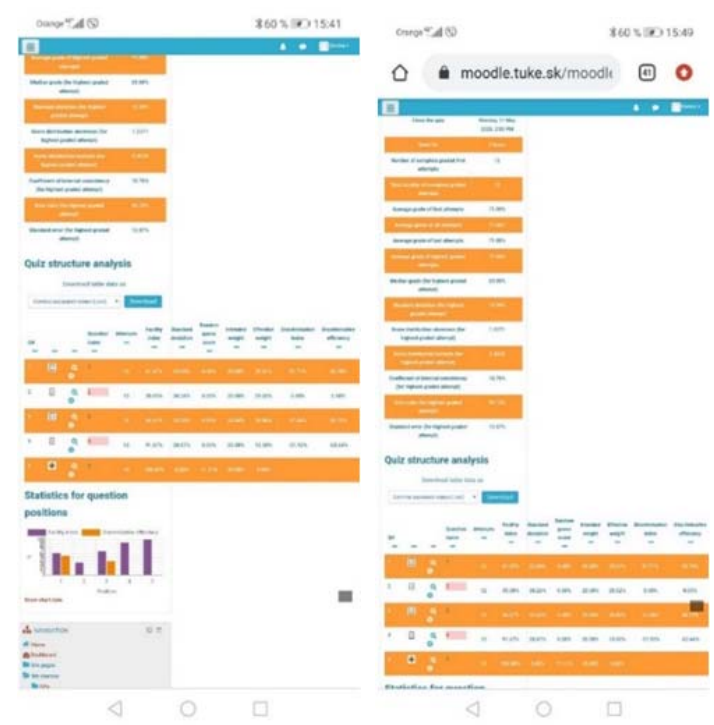

Figure 17. Moodle interpretation as M-learning toolStatistics and evaluation

\section{Conclusion}

The current education system provides several trends that facilitate access to information and improve the educational process. [12] One of such trends is the Moodle system, through which, as presented in this article, it is possible to make full use of current modern education systems such as Elearning and M-Learning. Based on the presented research, it can be stated that Moodle offers several tools that can be used in mobile education, while the biggest advantage in mobile education is considered to be time savings in study and teaching. Teaching can take place anytime and anywhere. Based on the real use and testing of the system in practice, it can be stated that the teaching of technically oriented subjects with the implementation of E-learning and M-learning is progressing, constantly improving and can be used in the educational process.

\section{Acknowledgements}

This research was supported by grant KEGA 030TUKE4/2018 Popularization and transfer the strategy Industry 4.0 into the technical study programs focusing on secondary schools and VEGA 1/0080/20 Research into the effect of high speed and high feed machining technologies on the surface integrity of hard-to-machine materials. 


\section{References}

[1]. Buranský, I., Morovič, L., \& Peterka, J. (2013). Application of Reverse Engineering for redesigning and manufacturing of a printer spare part. In Advanced Materials Research (Vol. 690, pp. 27082712). Trans Tech Publications Ltd.

[2]. Vieira, A. A. C., Dias, L. M. S., Santos, M. Y., Pereira, G. A. B., \& Oliveira, J. A. (2018). Setting an Industry 4.0 Research And Development Agenda For Simulation-A Literature Review. International Journal of Simulation Modelling (IJSIMM), 17(3).

[3]. Herzog, V. N., Buchmeister, B., Beharic, A., \& Gajsek, B. (2018). Visual and optometric issues with smart glasses in Industry 4.0 working environment. Advances in production engineering \& management, 13(4), 417.

[4]. Digital Learning plan,(2020). Wyoming's Digital Learning Plan (DLP). Retrieved from:

https://edu.wyoming.gov/in-the-

classroom/technology/digital-learning-plan/. [accessed: 18 September 2020].

[5]. Kolekar, S. V., Sanjeevi, S. G., \& Bormane, D. S. (2011). Acquisition of User's Learning Styles Using Log Mining Analysis through Web Usage Mining Process. In Intelligent Decision Technologies (pp. 809-819). Springer, Berlin, Heidelberg.
[6]. Gajsek, B., Marolt, J., Rupnik, B., Lerher, T., \& Sternad, M. (2019). Using maturity model and discrete-event simulation for Industry 4.0 implementation. International Journal of Simulation Modelling, 18(3), 488-499.

[7]. Kuric, I., Císar, M., Tlach, V., Zajačko, I., Gál, T., \& Więcek, D. (2018, September). Technical diagnostics at the department of automation and production systems. In International Conference on Intelligent Systems in Production Engineering and Maintenance (pp. 474-484). Springer, Cham.

[8]. Nichols, M. (2003). A theory for eLearning. Journal of Educational Technology \& Society, 6(2), 1-10.

[9]. Balogh, Z., \& Turčáni, M. (2011, November). Possibilities of modelling web-based education using IF-THEN rules and fuzzy petri nets in LMS. In International Conference on Informatics Engineering and Information Science (pp. 93-106). Springer, Berlin, Heidelberg.

[10]. Alioon, Y., \& Delialioğlu, Ö. (2019). The effect of authentic m-learning activities on student engagement and motivation. British Journal of Educational Technology, 50(2), 655-668.

[11]. Beňo, M., Gerhátová, Ž. (2009). Prečo je Moodle LCMS. Acta Facultatis Paedagogicae Universitatis Tyrnaviensis, 13, 44-52.

[12]. Zauskova, L., Czan, A., Sajgalik, M., Drbul, M., \& Rysava, Z. (2017). Triaxial measurement of residual stress after high feed milling using X-ray diffraction. Procedia engineering, 192, 982-987. 